Article

\title{
Persuasive Populism? Estimating the Effect of Populist Messages on Political Cynicism
}

\author{
Matthijs Rooduijn ${ }^{1}$, Wouter van der Brug ${ }^{1}$, Sarah L. de Lange ${ }^{1, *}$ and Jante Parlevliet ${ }^{2}$ \\ ${ }^{1}$ Department of Political Science, University of Amsterdam, 1001 NB Amsterdam, The Netherlands; \\ E-Mails:m.rooduijn@uva.nl (M.R.),w.vanderbrug@uva.nl (W.v.d.B.), s.l.delange@uva.nl (S. L. d. L.) \\ 2 Economics and Research Division, De Nederlandsche Bank, 1000 AB Amsterdam, The Netherlands; \\ E-Mail: j.parlevliet@dnb.nl \\ * Corresponding author
}

Submitted: 7 August 2017 | Accepted: 2 October 2017 | Published: 29 December 2017

\begin{abstract}
Many European countries have seen a growth of populism in recent years. Extant research shows that populist parties are increasingly successful, and that populist messages appear more frequently in the media. This raises the question to what extent populist messages affect public opinion. The aim of this study is to assess whether populist messages fuel political cynicism by arguing that an arrogant, selfish and complacent political elite does not listen to what ordinary people find important. Moreover, it assesses whether populist messages affect only those already favourably predisposed towards populist parties, or whether it affects citizens across the board. The results of a survey experiment, conducted in the Netherlands, suggests that individuals who are exposed to populist messages are indeed more cynical afterwards than individuals who are exposed to a very similar, but more 'neutrally formulated' message. However, the effects seem to be restricted to supporters of populist parties.
\end{abstract}

\section{Keywords}

media; political cynicism; populism; survey experiments

Issue

This article is part of the issue "Populism and the Remaking of (II)Liberal Democracy in Europe", edited by Lars Rensmann (University of Groningen, The Netherlands), Sarah L. de Lange (University of Amsterdam, The Netherlands) and Stefan Couperus (University of Groningen, The Netherlands).

(C) 2017 by the authors; licensee Cogitatio (Lisbon, Portugal). This article is licensed under a Creative Commons Attribution 4.0 International License (CC BY).

\section{Introduction}

Since the 1980s, populist parties have surged in Europe. Right-wing populist parties such as the Front National (FN) in France and the Partij voor de Vrijheid (PVV) in the Netherlands, and left-wing populist parties like Syriza in Greece and Podemos in Spain, have been electorally quite successful. In a number of countries, populist parties have governed, either as part of a coalition government (e.g. Austria, Greece, Finland, Italy, the Netherlands and Norway) or by absolute majority (e.g. Hungary and Poland). Also outside of party politics, populism has become more pervasive. Rooduijn (2014), for example, has found that as a consequence of the upsurge of pop- ulist parties, the populist message has also become increasingly widespread in the media (see also Manucci \& Weber, in press; Mazzoleni, 2008). Interestingly, in media outlets populist claims are not only made by the politicians that are being interviewed or cited, but also by journalists themselves (Hameleers, 2017). As a result some scholars have spoken about a populist 'Zeitgeist' in Europe (e.g. Mudde, 2004).

While much research exists on the causes of the pervasiveness of populism (for an overview see Mudde \& Kaltwasser, 2017), much less is known about the consequences thereof. Some scholars have argued that the rise of populism poses a threat to liberal democracy (e.g. Abts \& Rummens, 2007; Akkerman, 2003; Kaltwasser, 
2012; Mudde \& Kaltwasser, 2012). However, to empirically substantiate this claim, more knowledge is required about the consequences of the rise of populism. More particularly, we need to understand how the upsurge in populism affects the attitudes and behaviour of citizens. Our study focuses on one particular consequence, namely whether populist messages fuel political cynicism among citizens.

On the basis of cross-sectional data, Van der Brug (2003) provides evidence for his claim that the right-wing populist Pim Fortuyn fuelled political discontent by his anti-elite rhetoric. In a more recent study Rooduijn, Van der Brug and De Lange (2016) show that citizens who switch their support to populist parties become more discontented with politics. While these findings strongly suggest that populist messages can fuel discontent, we cannot know whether it is indeed the populist message that leads to such discontent. It is important therefore to test this causal claim in an experimental study, which is what we do here.

Our study is not the first experiment to examine the effects of exposure to populism. Bos, Van der Brug and De Vreese (2013), for example, investigate how mainstream right and radical right-wing populist politicians are evaluated when they express messages that are populist in nature. They find that only radical right-wing populist politicians are positively evaluated when they express such messages. Moreover, the effect is restricted to citizens who are already cynical about politics. Similarly, Hameleers and Schmuck (2017) show that citizens who are exposed to messages in which blame for negative developments is attributed to either the government or immigrants become more strongly populist in their attitudes. Yet, this effect is restricted to those that find the source of the message credible. Both experiments demonstrate that citizens' attitudes are influenced by the messages to which they are exposed, but that only citizens with attitudes that are already in line with the message are susceptible to be influenced. Sniderman, Hagendoorn and Prior (2004) refer to this as a 'galvanizing effect'.

We are not aware of experimental studies that focus on the effects of populist messages on political cynicism. To further our understanding of populism's impact, we therefore examine the effect of exposure to populist messages on political cynicism by means of a survey experiment. In the experiment we assign participants at random to a treatment or a control group. The participants in the first group are exposed to a text that contains a populist message, whereas the participants in the second group are exposed to a text that is highly similar in substance, but does not contain any populist messages. We assess whether individuals allocated to the first group report higher levels of political cynicism than individuals assigned to the second group. Moreover, we assess to what extent the treatment effect is conditional upon their support for populist parties. We find a clear effect of populist messages, but this effect is restricted to supporters of populist parties. They become more cynical about politicians as a result of their exposure to the populist message.

\section{Populism and Political Cynicism}

Many scholars define populism as a set of ideas in which the good people are pitted against the evil elite (Albertazzi \& McDonnell, 2008; Canovan, 2004; Mudde, 2004; Stanley, 2008). Mudde (2004, p. 543) describes populism as 'an ideology that considers society to be ultimately separated into two homogeneous and antagonistic groups, 'the pure people' versus 'the corrupt elite', and which argues that politics should be an expression of the volonté générale (general will) of the people'. He argues that populism is not a full ideology, such as conservatism, liberalism or socialism, but a 'thin-centred' ideology. It does not offer an all-encompassing worldview, but contains first and foremost ideas about the organization of democratic decision-making processes. In line with, for example, Canovan (2004), Hawkins (2010), Mudde (2004), and Taggart (2000), we conceptualize populism as a set of ideas, which consists of two related elements: 1) a negative portrayal of 'elites'; and 2) a glorification of 'the people'. A message should contain both elements in relation to each other to be qualified as populist. This conceptualization is both moralistic and antagonistic. According to Müller (2016, pp. 19-20), populism is 'a particular moralistic imagination of politics, a way of perceiving the political world that sets a morally pure and fully unified...people against elites who are deemed corrupt or in some other way morally inferior'.

According to many scholars, an important motive for supporting populist parties is to express discontent with the established parties. Betz (1994) argues that radical right-wing populist voters, which he labels 'protest voters', cast a ballot against 'the powers that be', which are held responsible for what goes wrong in society (see also Bergh, 2004). In other words, citizens support populist parties, because they are discontented with mainstream politicians and political parties. Most studies into the relationship between discontent and support for populist parties are based on correlations in cross-sectional data (e.g. Betz, 1994; Lubbers, Gijsberts, \& Scheepers, 2002; Mayer \& Perrineau, 1992; Norris, 2005). The interpretation of this correlation as a causal effect has been criticized. In particular Van der Brug (2003) and Rooduijn et al. (2016) have argued that the effect also runs the other way: the populist message fuels discontent. Rooduijn et al. (2016) refer to this as the 'fuelling discontent logic'. According to this logic citizens become more discontented with the functioning of politics as a consequence of being exposed to the messages of populist parties. In this paper we examine whether exposure to populist messages indeed fuels discontent.

Here we will focus on one specific form of discontent: political cynicism. Various scholars have demonstrated that we should distinguish various types of political dis- 
content (Dalton, 2004; Easton, 1965; Norris, 1999). Because populist messages most often focus on the antagonistic relationship between political elites and ordinary people, we assess the effects of the political message on political cynicism - a concept that taps into voters' discontent with politicians in general (see Agger, Goldstein, \& Pearl, 1961). In a recent study, Pattyn, Van Hiel, Dhont and Onraet (2012) have shown that political cynicism can (and should) be distinguished from related concepts like political trust, and that it is related to voting for populist parties.

The theoretical underpinning for the proposed mechanism can be found in the literature on voting behaviour, preference formation, and media exposure. Studies of public opinion indicate that the content of a message has a direct effect on the attitudes of those who are exposed to this message. For instance, a growing body of research has addressed the direct effects of media messages on public opinion (see Brandenburg \& Van Egmond, 2011). Studies have focused, for instance, on the impact of messages on voting behaviour (Druckman \& Parkin, 2005), candidate preferences (Dalton, Beck, \& Huckfeldt, 1998), and policy preferences (Zaller, 1992, 1996). Hence, there is ample evidence that citizens are directly influenced by the messages they are exposed to.

If this line of reasoning is extended to exposure to populism, it can be expected that if citizens are exposed to the message that political elites are failing, they might be inclined to incorporate this idea into their way of thinking about politics and become more politically discontented. This logic leads to our central expectation, which is:

H1: Exposure to populist messages leads to higher levels of political cynicism.

Our hypothesis is related to, but also distinct from, hypotheses that have been put forward in recent survey experiments. More specifically, our study differs from previous studies, such as Bos et al. (2013) and Hameleers and Schmuck (2017), in the causal relationship that is tested, as well as in the conceptualization of key terms. We will briefly outline the main differences between these studies and ours. Bos et al. (2013) investigate how mainstream right and radical right-wing populist politicians are evaluated when they express messages that are populist in nature. They find that only radical right-wing populist politicians are positively evaluated when they express such messages. Thus, Bos et al. (2013) look at how populist messages affect the evaluations of the individual politician expressing these messages. We, on the other hand, focus on the effect of populist messages in general on cynicism vis-à-vis politicians in general. More- over, Bos et al. (2013) employ a different definition of populism than the one we outlined above. Hameleers and Schmuck (2017) show that citizens who support populists are affected by their exposure to messages in which either the national government or immigrants are blamed for certain problems in society. As a result of their exposure, these citizens become more populist in orientation. Hence, Hameleers and Schmuck (2017) are interested in the effect of blame attribution on populist attitudes, and populism is the dependent variable in their study. We, on the other hand, examine the effect of populist messages on attitudes of cynicism, making populism the independent variable in our study. ${ }^{1}$ Thus, while related studies have been published, the impact of populist messages on political cynicism has not been examined yet.

Research into the effects of messages on voting behaviour and attitudes conclude that not all citizens are equally likely to be affected by their exposure. Based on consistency theories like, for instance, Festinger's (1957) theory of cognitive dissonance, we argue that individuals aim for consistency among attitudes and behaviours, and therefore evaluate (or even select) new information that is in line with their existing views and thereby tend to ignore information that runs counter to their views. As a consequence, we would expect to find a 'galvanizing effect', as Sniderman et al. (2004) called it, which means that new messages affect particularly those who are already inclined to agree with the message. To their own surprise, Sniderman et al. (2004) do not find evidence for such a 'galvanizing effect'. However, this may well be due to ceiling effects: the groups that Sniderman et al. (2004) study were already so negatively predisposed to immigrants that the experimental manipulation could not exert much effect any more.

Other studies do find evidence for a 'galvanizing effect'. Bos et al. (2013) show that populist messages make citizens more likely to support populist parties. Yet, this effect is restricted to voters who are already cynical. Hameleers and Schmuck (2017) find that only those citizens who supported the source of the message to which they were exposed were more likely to blame elites and immigrants. Citizens who opposed the source became actually less instead of more anti-establishment. In our study, the galvanizing effect would suggest that citizens who are already favourable to populist actors, such as populist politicians and parties, are more likely to become more cynical than citizens who do not support such actors. $^{2}$ We therefore hypothesize that:

H2: The effects of the exposure to populist messages is stronger for citizens who support populist parties than for citizens who support non-populist parties.

\footnotetext{
${ }^{1}$ Hameleers and Schmuck (2017) conceptualize populism in a way similar to ours, namely as a combination of glorification of 'normal' citizens and denunciation of the elite.

2 Attitudes are not only affected by the messages to which individuals are exposed, but also by the source of those messages and by characteristics of its recipients (see Olson \& Zanna, 1993). In this study we keep the source of the message constant. We assess, however, to what extent the effect of the populist message is different for audiences with diverging political preferences.
} 


\section{Research Design}

In order to test our hypothesis that exposure to populist messages leads to more political cynicism, we conduct a survey experiment. More specifically, we use a randomized post-test design in which participants read a newspaper article created by the researchers and subsequently answer questions concerning their attitudes and behaviour. One (randomly selected) group of participants is exposed to a newspaper article, which includes populist messages. The other group of participants reads an article which is highly similar in substance, but which does not contain any populist messages. Survey experiments have two advantages over other research designs. First, we know to which messages the participants are exposed (see Tilley \& Hobolt, 2011). On the other hand, when using non-experimental research designs, we can ask people which newspapers they read regularly and we can content analyse these outlets. Yet, we can never know whether respondents actually read the newspaper articles that were analysed. Secondly, because participants are randomly assigned to the experimental conditions, alternative explanations for differences between groups of participants can be ruled out. This is not possible in survey-based studies, where respondents make their own selection of outlets.

Our survey experiment is carried out in the Netherlands. The Netherlands is an appropriate case, because, in comparison with many other countries, the populist discourse is relatively common in this country-both in the political realm and in the mass media (Rooduijn, 2014). This is an important requirement, because in a country where populism is not very common in the public debate, a constructed populist article would not be very credible as a 'real life' media message. Moreover, in the Netherlands populism can be found both on the left and the right of the political spectrum (De Lange \& Rooduijn, 2011), which makes it possible to examine the impact of populism tout court, rather than only that of radical right-wing populism.

Our stimulus is a (fictitious) newspaper article (created by the researchers) about the electoral losses of mainstream parties in the Dutch national elections of 2017. We constructed two different articles: one that contains a populist message (experimental group) and one that does not (control group). ${ }^{3}$ The first two paragraphs of the newspaper articles are identical and concern a description of the situation. The third paragraph differs between the control and experimental groups and contains the interpretation of the results by a political an- alyst. In the text given to the treatment group this analysis includes populist messages. These are references to 'the establishment', which has lost touch with 'the wishes of ordinary citizens'. The messages in the control group are much more neutral in tone. The exact wordings of the last paragraphs of our texts can be found in the Appendix.

Before we organized our survey experiment, we conducted a pilot study. It was distributed in the Netherlands between August $25^{\text {th }}$ and August $29^{\text {th }}, 2014$ by means of social media (Facebook, E-mail and Twitter) $(N=128)$. The newspaper article in the pilot study discussed the 2014 elections to the European Parliament, but was in terms of the presented populist messages almost equal to the text presented in the Appendix. Although as a result of our method of convenience sampling the findings are not representative for the Dutch population, the treatment effect turned out to be statistically significant (at $p<.10$ ) and in the expected direction (results are available upon request). We therefore proceeded with our experiment.

Our survey experiment was appended to the June edition of the DNB Household Survey (DHS), conducted by CentERdata at Tilburg University. This panel includes approximately 2,000 households (from which one or more household members take part), which are representative of the Dutch population (see, e.g., Guiso, Sapienza, \& Zingales, 2008; Parlevliet, 2017). The survey experiment was presented between June $5^{\text {th }}$ and June $20^{\text {th }}, 2017$ to 3,035 individuals, out of which 2,381 completed the questionnaire (response rate of $78.5 \%$ ).

We aimed to create two similar groups by randomly distributing the two stimuli to the respondents. As a result of this procedure, $51 \%$ of the respondents ended up in the experimental condition and $49 \%$ in the control group (see Table 1). The two groups were compared on various characteristics that may be correlated with political cynicism, such as age, education, gender, subjective class and religiosity. We do not find any statistically significant differences between the control and experimental groups on these characteristics, which indicates that the two groups are equivalent. ${ }^{4}$

To measure our dependent variable, political cynicism, respondents were asked to express their agreement or disagreement with eight statements: 1) politicians are honest; 2) politicians are profiteers; 3) politicians keep their promises; 4) politicians are corrupt; 5) politicians are reliable; 6 ) politicians are just smooth talkers; 7) politicians do not understand what is going on in society; and 8) politicians are capable of solving prob-

\footnotetext{
${ }^{3}$ We decided to employ fictitious newspaper articles because this allowed us to fully control the messages participants were exposed to and thereby to guarantee the internal validity of our study. However, to enhance external validity, we based the stimuli on existing newspaper articles following the Dutch elections (see Hameleers, Bos, \& De Vreese, 2017, p. 879).

${ }^{4}$ To assess whether the respondents were aware of the experimental manipulation, we also conducted a manipulation check by asking the respondents the following question: 'In the commentary of the political sociologist, reference is made to a cleavage between what politicians and what ordinary citizens find important'. A $t$-test $(t=-1.03 ; d f=2356 ; p=0.150)$ shows that the two groups differ from each other in the expected direction, but that the differences are not statistically significant (also when distinguishing populist from non-populist voters). While our treatment did affect our dependent variable 'political cynicism', we have no evidence that respondents were aware of the populist tone to which they were exposed. In the concluding section we elaborate on the implications.
} 
lems in society. Respondents could answer on a 5-points scale from 'fully agree' to 'fully disagree'. We combined these items into a scale, which ranges from 1 (not at all cynical) to 5 (very cynical). The Cronbach's Alpha for this scale is 0.90 , which is above the traditional cut-off point for scale reliability.

To measure whether citizens supported a populist party prior to participating in the experiment, we asked them for which party they had voted in the national elections of March $15^{\text {th }}, 2017$. In line with research on populism in the Netherlands, we subsequently coded a vote for the Forum voor Democratie (FvD), Geen Peil, Partij voor de Vrijheid (PVV), Socialistische Partij (SP), and Voor Nederland (VNL) as support for a populist party (e.g. De Lange \& Rooduijn, 2011), while a vote cast for any of the other parties that participated in the elections was coded as support for a non-populist party. ${ }^{5}$ Of the 2,381 participants who completed the survey, 2,184 participants voted in the 2017 elections. Of those voters 421 respondents supported a populist party, while 1,643 respondents supported a non-populist party.

Table 1 lists the descriptive statistics of the variables for the entire group of respondents. Political cynicism is our dependent index variable and ranges from 1 (not at all cynical) to 5 (very cynical). Populist message is a dummy variable taking the value of 1 when respondents have been 'treated' with the populist message and taking the value of 0 when respondents have received the neutral message. Populist vote is a dummy variable for respondents who voted, where 1 indicates they voted for one of the populist parties mentioned above. The last four rows show the four combinations of having received the populist or the neutral message and having voted for a mainstream or a populist party. The means represent the proportion of respondents in the four groups. Since fewer respondents voted for a populist than for a mainstream party the two conditions with populist voters both contain $10 \%$ of the respondents, while the other two both contain roughly $39 \%$ and $41 \%$.

\section{Results}

Our main expectation is that those who have been exposed to the text containing populist messages will be on average more cynical than those who have been exposed to the neutral text $(\mathrm{H} 1)$. In Table 2 we assess whether the mean political cynicism scores are different for the control and experimental groups. We conduct an independent samples $t$-test for which we assume equal variances, since Levene's test indicates that the hypothesis that the variances in the two groups are equal cannot be rejected. Participants that have not been exposed to the populist messages have an average cynicism score of 3.10, whereas participants that have been exposed to the populist messages have an average score of 3.14. This leads to a mean difference score of 0.04 , which is significant at $p<.10$ (one-tailed). Hence, those who have been exposed to the populist messages score, on average, higher on the scale of political cynicism than those who have not been exposed to such messages.

Table 1. Descriptive statistics.

\begin{tabular}{llllll}
\hline & Count & mean & sd & min & max \\
\hline Political cynicism & 2,360 & 3.12 & 0.68 & 1.1 & 5 \\
Populist message (1 = yes) & 2,381 & 0.51 & 0.50 & 0 & 1 \\
Populist vote (1 = yes) & 2,064 & 0.20 & 0.40 & 0 & 1 \\
\hline Populist message + populist vote & 2,064 & 0.10 & 0.30 & 0 & 1 \\
Populist message + non-populist vote & 2,064 & 0.41 & 0.49 & 0 & 1 \\
Neutral message + populist vote & 2,064 & 0.10 & 0.30 & 0 & 1 \\
Neutral message + non-populist vote & 2,064 & 0.39 & 0.49 & & 1 \\
\hline$N$ & 2,381 & & &
\end{tabular}

Table 2. Scores on scale of political cynicism.

\begin{tabular}{|c|c|c|c|}
\hline & \multicolumn{2}{|c|}{ Political cynicism } & \multirow[b]{2}{*}{$\mathrm{N}$} \\
\hline & Mean & Standard Error & \\
\hline Without populist message & 3.10 & 0.02 & 1,151 \\
\hline With populist message & 3.14 & 0.02 & 1,209 \\
\hline Combined & 3.12 & 0.01 & 2,360 \\
\hline Difference & $-0.04^{\wedge}$ & 0.03 & \\
\hline
\end{tabular}

Note: Political cynicism is measured on a scale from $1-5$, where $1=$ not at all cynical, and $5=$ very cynical

** $p<0.01 ; * p<0.05 ;{ }^{\wedge} p<0.10$

\footnotetext{
${ }^{5}$ As an alternative operationalization, we also included the elderly party 50+ in the group of populist parties. The analyses with this alternative operationalization yield largely identical findings and do not alter our conclusions.
} 
Our findings demonstrate an effect of the populist message on participants' level of cynicism, be it only significant at the $p<.10$ level. The difference of 0.04 on a 5-point scale is obviously small. However, it is important to keep in mind that we only manipulated the wording of two sentences in a newspaper article. It would be unrealistic therefore to expect much larger differences between the two groups and in reality citizens are much more frequently exposed to populist statements. We will discuss this further in the concluding section.

We also tested whether the supporters of populist parties were more strongly affected by their exposure to the populist message than the supporters of other parties $(\mathrm{H} 2)$. Table 3 presents the results of a multiple regression, which demonstrates that this effect is indeed stronger for the supporters of populist parties. In fact, the effect is only present for the supporters of populist parties $(b=.181 ; p=.008)$; the supporters of other parties are not significantly more likely to be cynical after being exposed to the manipulated message than when being exposed to a more 'neutral' message.

Figure 1 presents these results graphically. The solid line shows the two conditions in which respondents were exposed to a neutrally worded newspaper article, while the dotted line shows the conditions in which respondents were exposed to populist messages. It shows that the level of cynicism is already considerably higher among populist voters than among non-populist voters, also when they are exposed to a neutral message (compare the two groups on the straight line). Yet, the dotted line is steeper, and the difference between the groups
Table 3. Effects on political cynicism: Interaction between exposure and support for populist parties.

\begin{tabular}{lc}
\hline & Model 1 \\
\hline Populist message & .029 \\
& $(.031)$ \\
\hline Populist vote & $.601^{* *}$ \\
& $(.048)$ \\
\hline Populist message * Populist vote & $.181^{* *}$ \\
& $(.068)$ \\
\hline Constant & 2.923 \\
& $(.022)$ \\
\hline 2 & .171 \\
$N$ & 2,057 \\
\hline
\end{tabular}

Note: Political cynicism is measured on a scale from 1-5, where $1=$ not at all cynical, and $5=$ very cynical

** $p<0.01$; $^{*} p<0.05$; $^{*}<0.10$

being exposed to a populist text and those being exposed to a neutral text is only significant among populist party voters (at the right hand side of the graph). Among mainstream party voters the experimental treatment did not exert a significant effect (see the left hand side of the graph. Thus, after exposure to populist messages the gap between the two groups of voters in terms of their level of cynicism is larger than prior to their exposure. This could point towards a spiral of cynicism among the supporters of populist parties. ${ }^{6}$

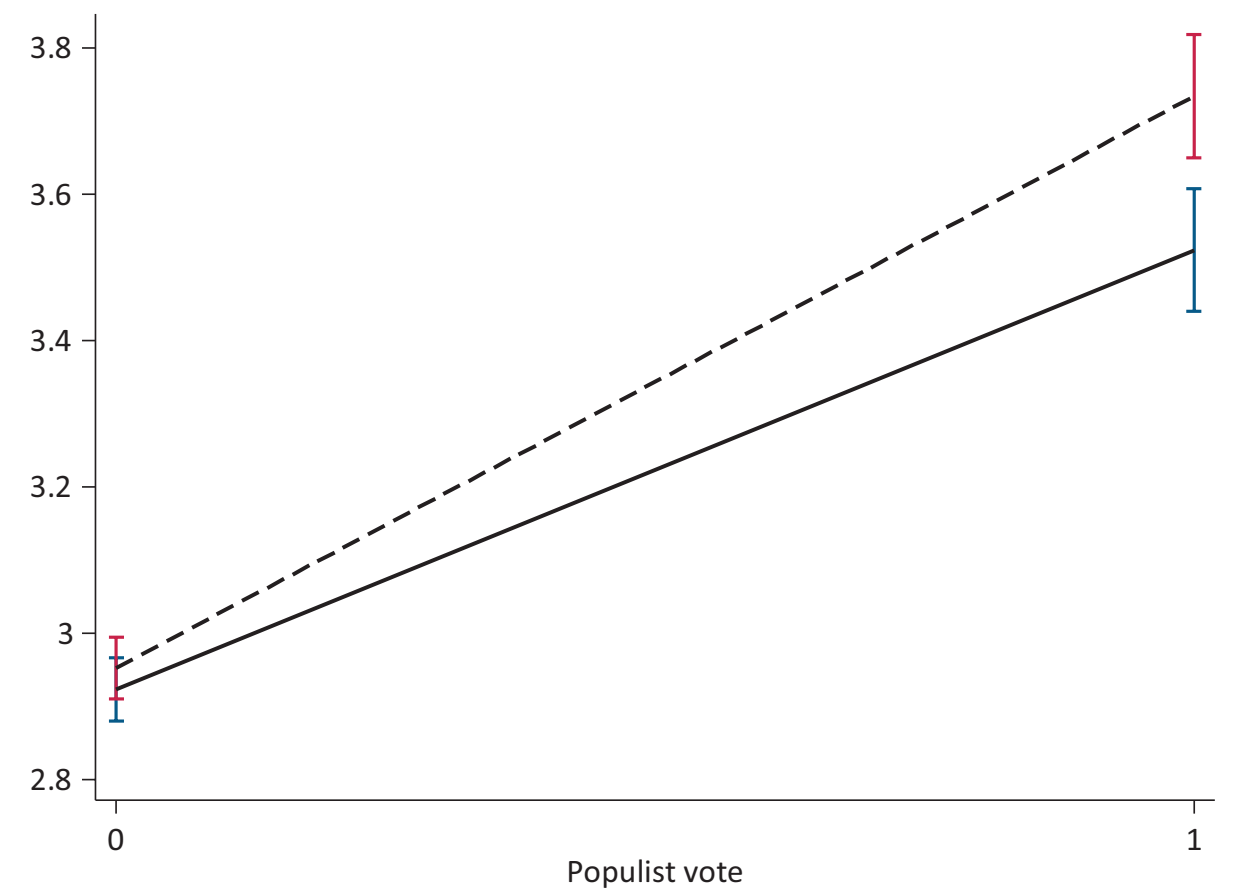

Figure 1. Predicted values of political cynicism for supporters of populist (1) and non-populist parties (0), and those who are exposed to a populist message (dotted line) and non-populist message (solid line).

\footnotetext{
${ }^{6}$ We have also looked at the effects of our experimental treatment on other subgroups. First of all, we distinguished voters for the left-wing populist SP and the various right-wing populist parties. While the effect was somewhat weaker among SP voters, the effect was not significantly different from
} 


\section{Conclusion}

There is a general concern that populism is not only a corrective, but also a challenge to liberal democracy (e.g. Abts \& Rummens, 2007; Akkerman, 2003; Kaltwasser, 2012; Mudde \& Kaltwasser, 2012). In this study we investigate whether the pervasiveness of populism threatens liberal democracy by affecting citizens' attitudes in a negative way. To this end we examine the 'fuelling discontent logic', which argues that exposure to populist messages fuels cynicism about politics (Rooduijn et al., 2016; Van der Brug, 2003). After all, according to populist actors - such as populist politicians, parties, and mediaestablished politicians have no idea what ordinary people find important and only focus on their own interests. Moreover, they point towards a failure of representation and representative institutions, such as parties and parliaments.

Based on a survey experiment, in which we have randomly assigned participants to two different groupsone group in which individuals have been exposed to a text containing populist messages and another group in which individuals have been exposed to a neutral textwe conclude that exposure to populist messages indeed fuels political cynicism. Yet, the main effect is small, and marginally significant at the most, given the $p$-value of 0.091 . When we distinguished respondents according to their support for parties, it becomes clear, however, that the effect takes place only among supporters of populist parties. The effect in this group is highly significant (at $p<.01$ ), while no effect was observed among the voters for other parties. We may thus conclude that voters for populist parties become more politically cynical when being exposed to populist messages, while other voters are not affected.

What does this mean? On the one hand, this suggests that the persuasiveness of the populist message should not be overestimated. We asked respondents to report their levels of political cynicism directly after we exposed them to a treatment. And even immediately after the treatment the effect is limited. It might therefore well be the case that the effect quickly disappears when time passes by. On the other hand, our study shows that even a small manipulation of two 'populist worded' sentences in a newspaper article do affect attitudes about politics. It thus seems plausible that continued exposure to populist messages brings about more cynicism.

One limitation of our study is that we focus on an effect of one small manipulation of a text. Our manipulation check suggests that the respondents did not realize that these messages are populist. This could mean that other differences between the texts presented to the experimental and control group produced the differences in political cynicism, but given the slight manipulation and the large similarities between the two texts, we find that implausible. A more plausible reason could be that populist messages have become so pervasive that many citizens do not even notice them anymore. That such messages nonetheless exert an effect on political cynicism is therefore an important finding.

Another limitation of our study is that we look at short-term effects only (of a change in the wording of two sentences). However, in real life citizens are continuously exposed to many populist messages. In future studies researchers may wish to focus on long-term effects of repeated exposure to populist messages. Yet, it may not be feasible to study this in a controlled experiment. Another obvious limitation of our study is that we have assessed the effect of populist messages in only one specific country-the Netherlands. We have no theoretical reasons to expect the effects to be different in other national contexts, but whether our findings can indeed be replicated in other contexts remains to be shown empirically. Finally, respondents with anti-elite attitudes may also feel negatively disposed to academics who conduct this type of research. However, if this would have caused those who are most susceptible to the populist message to opt out of the study, our findings are likely to err on the conservative side.

Our findings contribute to the relatively young literature on the societal and political consequences of the rise of populism. These studies indicate that populism is spreading through a series of mechanisms of 'contamination'. The success of populist parties impacts on media populism, while the pervasiveness of populism in politics and media in turn affects the attitudes of specific groups of citizens. As a result of their exposure to populist messages, citizens' political cynicism becomes stronger. However, this 'spiral of discontent' is only present among those voters who were already supportive of populist parties to begin with. Because of their tendency to select and evaluate information on the basis of their already existing convictions, they become more discontented when their beliefs about the failures of politics are confirmed. Hence, we might be witnessing a vicious cycle of discontent among certain groups of citizens, which might erode their support for liberal democracy in the long run. The consequence is a further polarization of attitudes towards politicians.

A certain level of scepticism towards politicians is essential for a democracy to function well, so we do not want our conclusion to sound too 'alarmist'. As long as cynicism is directed at politicians, rather than at the democratic system as such, this is perfectly compatible

the effect among right-wing populist party voters. We also looked at the difference between voters and non-voters. The experimental treatment had a weaker effect among the non-voters than among voters. Yet here also, the difference was not significant. In both cases we were looking at rather small subgroups of our sample. So, the failure to reject the null-hypothesis could be the result of the small $N$, which is why we do not report the results of these tests in detail. They are available upon request. 
with a healthy democracy. However, there is always a risk of spill-over effects (Easton, 1965), where an erosion of specific support leads to decreases in diffuse support. This would be much more harmful to democratic support and legitimacy.

\section{Acknowledgments}

The authors would like to thank Miquelle Marchand of CentERdata for her feedback on the questionnaire, and the participants of the panel 'The Study of Populism Through Experiments' at ECPR General Conference 2014 and the Team Populism Conference 2015 for their comments on an earlier version of this manuscript.

\section{Conflict of Interests}

The authors declare no conflict of interests.

\section{References}

Abts, K., \& Rummens, S. (2007). Populism versus democracy. Political Studies, 55(2), 402-424.

Agger, R. E., Goldstein, M. N., \& Pearl, S. A. (1961). Political cynicism: Measurement and meaning. The Journal of Politics, 23(3), 477-506.

Akkerman, T. (2003). Populism and democracy: Challenge or pathology? Acta Politica, 38(2), 147-159.

Albertazzi, D., \& McDonnell, D. (2008). Introduction: The sceptre and the spectre. In D. Albertazzi \& D. McDonnell (Eds.), Twenty-first century populism. New York, NY: Palgrave Macmillan.

Bergh, J. (2004). Protest voting in Austria, Denmark, and Norway. Scandinavian Political Studies, 27(4), 33673389.

Betz, H.-G. (1994). Radical right-wing populism in Western Europe. Houndsmill and Basingstoke: Macmillan.

Bos, L., Van der Brug, W., \& De Vreese, C. (2013). An experimental test of the impact of style and rhetoric on the perception of right-wing populist and mainstream party leaders. Acta Politica, 48, 192-208.

Brandenburg, H., \& Van Egmond, M. (2011). Pressed into party support? Media influence on partisan attitudes during the 2005 UK general election campaign. British Journal of Political Science, 42(2), 441-463.

Canovan, M. (2004). Populism for political theorists? Journal of Political Ideologies, 9, 241-252.

Dalton, R. J. (2004). Democratic challenges, democratic choices. Oxford: Oxford University Press.

Dalton, R. J., Beck, P. A., \& Huckfeldt, R. (1998). Partisan cues and the media: Information flows in the 1992 presidential elections. The American Political Science Review, 92(1), 111-126.

De Lange, S. L., \& Rooduijn, M. (2011). Een Populistische Tijdgeest in Nederland? Een Inhoudsanalyse van de Verkiezingsprogramma's van Politieke Partijen [A populist zeitgeist in the Netherlands? A content analysis of the election programs of political parties].
In R. Andeweg \& J. Thomassen (Eds.), Democratie Doorgelicht: Het Functioneren van de Nederlandse Democratie [Democracy investigated: How Dutch democracy works] (pp. 319-334). Leiden: Leiden University Press.

Druckman, J. N., \& Parkin, M. (2005). The impact of media bias: How editorial slant affects voters. The Journal of Politics, 67(4), 1030-1049.

Easton, D. (1965). A systems analysis of political life. New York, NY: Wiley.

Festinger, L. (1957). A theory of cognitive dissonance. Stanford, CA: Stanford University Press.

Guiso, L., Sapienza, P., \& Zingales, L. (2008). Trusting the stock market. The Journal of Finance, 63(6), 25572600.

Hameleers, M. (2017). They did it! The content, effects, and mechanisms of blame attribution in populist communication. Amsterdam: University of Amsterdam.

Hameleers, M., Bos, L., \& De Vreese, C. H. (2017). "They did it": The effects of emotionalized blame attribution in populist communication. Communication Research, 44(6), 870-900.

Hameleers, M., \& Schmuck, D. (2017). It's us against them: A comparative experiment on the effects of populist messages communicated via social media. Journal of Information, Communication \& Society, 20(9), 1425-1444.

Hawkins, K. A. (2010). Venezuela's Chavismo and populism in comparative perspective. Cambridge: Cambridge University Press.

Kaltwasser, C. R. (2012). The ambivalence of populism: Threat and corrective for democracy. Journal of Democratization, 19(2), 184-208.

Lubbers, M., Gijsberts, M., \& Scheepers, P. (2002). Extreme right-wing voting in Western Europe. European Journal of Political Research, 41, 345-378.

Mannuci, L., \& Weber, E. (in press). Why the big picture matters: Political and media populism in Western Europe since the 1970s. Swiss Political Science Review.

Mayer, N., \& Perrineau, P. (1992). Why do they vote for Le Pen? European Journal of Political Research, 22, 123-141.

Mazzoleni, G. (2008). Populism and the media. In D. Albertazzi \& D. McDonnell (Eds.), Twenty-first century populism (pp. 49-64). New York, NY: Palgrave Macmillan.

Mudde, C. (2004). The populist zeitgeist. Government and Opposition, 39, 541-563.

Mudde, C., \& Kaltwasser, C.R. (Eds.). (2012). Populism in Europe and the Americas: Threat or corrective for democracy? Cambridge: Cambridge University Press.

Mudde, C., \& Kaltwasser, C. R. (2017). Populism: A very short introduction. Oxford: Oxford University Press.

Müller, J.-W. (2016). What is populism? Philadelphia, PA: University of Pennsylvania Press.

Norris, P. (Ed.). (1999). Critical citizens: Global support for democratic government. Oxford: Oxford University Press. 
Norris, P. (2005). Radical right: Voters and parties in the electoral market. New York, NY: Cambridge University Press.

Olson, J. M., \& Zanna, M. P. (1993). Attitudes and attitude change. Annual Review of Psychology, 44(1), 117-154.

Parlevliet, J. (2017). What drives public acceptance of reforms? Longitudinal evidence from a Dutch pension reform. Public Choice, 173(1/2), 1-23.

Pattyn, S., Van Hiel, A., Dhont, K., \& Onraet, E. (2012). Stripping the political cynic: A psychological exploration of the concept of political cynicism. European Journal of Personality, 26(6), 566-579.

Rooduijn, M. (2014). The mesmerising message: The diffusion of populism in public debates in Western European media. Political Studies, 62(4), 726-744.

Rooduijn, M., Van der Brug, W., \& De Lange, S. L. (2016). Expressing or fuelling discontent? The relationship between populist voting and political discontent. Electoral Studies, 43, 32-40.

Sniderman, P. M., Hagendoorn, L., \& Prior, M. (2004).
Predisposing factors and situational triggers: Exclusionary reactions to immigrant minorities. American Political Science Review, 98(1), 35-49.

Stanley, B. (2008). The thin ideology of populism. Journal of Political Ideologies, 13, 95-110.

Taggart, P. (2000). Populism. Philadelphia, PA: Open University Press.

Tilley, J., \& Hobolt, S. B. (2011). Is the government to blame? An experimental test of how partisanship shapes perceptions of performance and responsibility. The Journal of Politics, 73(2), 316-330.

Van der Brug, W. (2003). How the LPF fuelled discontent: Empirical tests of explanations of LPF support. Acta Politica, 38, 89-106.

Zaller, J. (1992). Nature and origins of mass opinion. Cambridge: Cambridge University Press.

Zaller, J. (1996). The myth of massive media impact revived: New support for a discredited idea. In D. Mutz, R. Brody, \& P. Sniderman (Eds.), Political persuasion and attitude change (pp. 17-79). Ann Arbor, MI: University of Michigan Press.

\section{About the Authors}

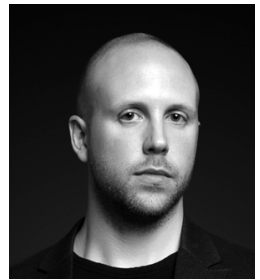

Matthijs Rooduijn is Assistant Professor in the Department of Political Science at the University of Amsterdam. Previously, he was Assistant Professor in the Department of Sociology at Utrecht University and a postdoctoral researcher at the Amsterdam Centre for Inequality Studies (AMCIS). His research examines the causes and consequences of the rise of populist and radical political parties and attitudes. He recently co-edited the book Radical Right-Wing Populist Parties in Western Europe (Routledge).

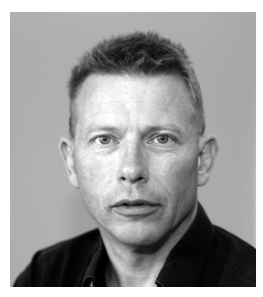

Wouter van der Brug is Professor of Political Science at the University of Amsterdam. His research focuses on electoral processes in international comparative perspective, including voting behaviour, changes in party systems, and the rise of right-wing populist parties. He publishes regularly on these topics in international journals. In 2016, Oxford University Press published a volume that he edited together with Claes de Vreese, (Un)intended Consequences of EU Parliamentary Elections.

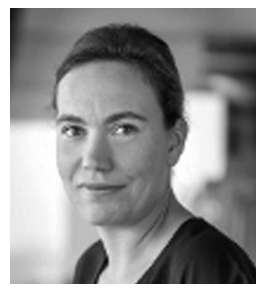

Sarah L. de Lange is Professor by special appointment at the Department of Political Science at the University of Amsterdam. Since 2016 she holds the Dr. J. M. Den Uyl chair. Her main research interests concern parties, party families, and party systems, and in particular the rise of radicalism, populism, and extremism in contemporary democracies. Her latest edited volume, entitled Radical Right-Wing Populist Parties in Western Europe: Into the Mainstream? has appeared in 2016 with Routledge.

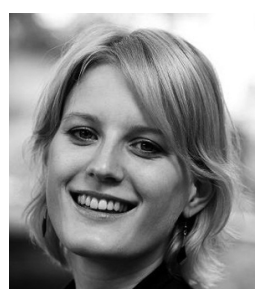

Jante Parlevliet is head of the Economic Policy Department of De Nederlandsche Bank. Prior to joining DNB in 2011, she worked at the Social and Economic Council of the Netherlands and the OECD. She obtained MSc. degrees in Political Science and Economics at the University of Amsterdam, where she is currently also pursuing a part-time PhD in Economics on the political economy of economic reforms. 


\section{Appendix}

The first two paragraphs of the text in the survey experiment concern the results of the elections to the national parliament in the Netherlands in March 2017. The third (and last) paragraph in both texts contains an analysis of a political commentator. In the first text populist messages are included in the analysis, in the second text the analysis is neutral.

\section{Text 1 (does include populist messages)}

"According to political sociologist Matthijs Rooduijn this development sends an important message. 'The gains made by parties such as UKIP and Front National clearly show that the establishment has no idea of what the man in the street finds important. The voter has the feeling that established parties barely take into account what ordinary citizens want'. According to Rooduijn, the establishment could win its lost seats back if it would listen better to hardworking citizens".

\section{Text 2 (does not include populist messages)}

"According to political sociologist Matthijs Rooduijn this development sends an important message. 'The gains made by parties such as UKIP and Front National clearly show that the message of these parties appeals to a large share of the electorate. A substantial number of voters believe that parties do not offer proper solutions to important social problems'. According to Rooduijn, parties could win their lost seats back if they took more account the ideas of their own grassroots". 